\title{
Promoting Physics-Entrepreneurship Via Facebook: A Thematic Study
}

\author{
Nadi Suprapto $^{1 *}$, Hasan Nuurul Hidaayatullaah ${ }^{2}$ \\ ${ }^{1,2}$ Universitas Negeri Surabaya, Faculty of Mathematics and Natural Sciences, Department of \\ Physics, Indonesia \\ *Correspondence: nadisuprapto@unesa.ac.id
}

\begin{tabular}{ll}
\hline Kbstract \\
\hline Science & This study addresses the use of Facebook (FB) as a media for promoting science' \\
Entrepreneurship & product. By adopting the concept of entrepreneurship education, the study explored the \\
Facebook & role of FB in promoting science message through "Learning Shirt-theme". A thematic \\
Thematic study & (34 members) in FB namely "Learning Shirt" and the content of their sites as the \\
& entrepreneurs and 192 active members as the service users. The students pursued their \\
study at a public university in Surabaya, Indonesia, which contributed to the group's \\
community. These groups of students established entrepreneurship activities and \\
promoted their message of physics via FB. The role of the researcher is a tutor of the \\
community. Data analyses were used, including a thematic and documentation analysis \\
and supported by questionnaire analysis. The results of the study categorized the \\
physics-shirt into five themes: the history of physics, derivation of the equation in \\
physics, physics symbols and equations, physics values, and models in physics. The \\
FB users' understanding of physics themes were in a good category with an average \\
score of 79.79. The trend of FB user's positive response regarding ten expressions in \\
the questionnaire was increased significantly in three weeks.
\end{tabular}

To cite this article:

Suprapto, N., \& Hidaayatullaah, H. N. (2021). Promoting Science-Entrepreneurship via Facebook: A Thematic Study. Thabiea : Journal of Natural Science Teaching, Vol. 4(1), 116.

\section{Introduction}

\section{Entrepreneurship Education}

Nowadays, entrepreneurship education and skill acquisition become point attention around the world. Entrepreneurship has branched into several dimensions, including science, technology, social, business, environment, gender, etc. Therefore, there were established some combination terms: science or scientifically entrepreneurship (Armstrong \& Tomes, 2000; Deveci \& Çepni, 2017), technological entrepreneurship (Akani, 2012; Chang, Benamraoui, \& Rieple, 2014; Karimi, Biemans, Lans, Aazami, \& Mulder, 2016; McEwen, 2013; Nacu \& Avasilcăi, 2014; Yazıcı, Uslu, \& Arık, 2016), social entrepreneurship (Chang, Benamraoui, \& Rieple, 2014; Yazıc1, Uslu, \& Arık, 2016), business-entrepreneurship education (Karimi, Biemans, Lans, Aazami, \& Mulder, 2016), environmental/ecological/green entrepreneurship or ecopreneurship (McEwen, 2013; Nacu \& Avasilcăi, 2014), and technological ecopreneurship.

Technological entrepreneurship covers the integration of technology and entrepreneurship. As a consequence, it represents the combination of ecological 
entrepreneurship and technological entrepreneurship (Nacu \& Avasilcăi, 2014). Meanwhile, scientifically entrepreneurship embodies science and entrepreneurship (Deveci \& Çepni, 2017). Because science includes biology, chemistry, physics, environmental, and earth science, it triggers the initiation of science-entrepreneurship, biology-entrepreneurship, chemistry-entrepreneurship, physics-entrepreneurship, and so on. Taking, for example, two researchers investigated senior physics teachers in the secondary school of Nigeria in relating to the assessment of entrepreneurial skills (Agommuoh \& Akanwa, 2014) as well as researchers who focused on chemistry curriculum (Nwakaego \& Kabiru, 2015). Another researcher has also conducted research about entrepreneurship in biology education (Ejilibe, 2012). Entrepreneurship in STEM (Science, Technology, Engineering and Mathematics) Education area has also been investigated by a group researcher from Africa (Ezeudu, Ofoegbu, \& Anyaegbunnam, 2013).

\section{Facebook as Educational Media}

Currently, there are many social networking sites such as Facebook (FB), Twitter, Line, Instagram, Whatsapp, LinkedIn, Foursquare, MySpace, and video sharing like YouTube. Among them, the existence of FB was earlier established as a platform of digital society (Gapsalamov, Bochkareva, Akhmetshin, Vasilev, \& Anisimove, 2020). In more than two decades since its launch in 2004, it has quickly become a backbone among users. The data showed that "the number of Facebook users in the last quarter 2019 has reached 2.5 billion per month whereas, at the beginning of 2013, the number of active Facebook users surpassed one billion" (Clement, 2020). It is estimated that the total of FB users will grow dramatically with most users living outside of the USA (Clement, 2020). In the case of Indonesia, "there were 136,960,000 Facebook users in Indonesia in January 2019, which accounted for 50.2\% of its entire population" (NapoleonCat, 2019). Boyd \& Ellison (2007) endorsed three appearances to excuse for the willingness subscription rate of FB from their research: "an ability of Facebook to allow users to construct a public or semi-public profile; the ability to identify other users with whom a connection is present; and the ability of the users to view and track their connections as well as those made by others".

FB is the favorite social networking among university students themselves (Cheung, Chiu, \& Lee, 2011). A large proportion of FB users are "between 18 and 25 years old, and those are mostly university students" (Bumgarner, 2007). Some preceding researchers concerned the use of FB as media for online and distance learning (Arouri, 2015; Dhyab \& Varol, 2018; Jumaat, et al., 2019; Kocdar, Karadeniz, \& Goksel, 2018; Shraim, 2014). The features in FB are useful for teaching and learning process, especially in fostering of interaction, activating participation, promoting collaboration, and facilitating critical thinking (Mason, 2006). Research on university students' use of FB has scrutinized the impression of FB use on students' performance and skills (Sanchez-Franco, Villarejo-Ramos, \& MartinVelicia, 2011); use of FB in university libraries (Scale, 2008). Students want to take part in a suitable technology for learning and interact with the learning environment (Teo, 2016). Other studies have scrutinized the influence of FB use on students' self-confidence, emotional, and social adjustment (Kalpidou, Costin, \& Morris, 2011), and students' level of sociability (Ellison, Steinfield, \& Lampe, 2007). Moreover, previous researchers were also focused on 
the use of FB as a social application for students to learn business, and for leisure that inspiring this study (Scale, 2008).

\section{Physics-Entrepreneurship via Facebook}

Although FB is typically used for discussing either general or academic topics, this site takes advantage of it as a platform for entrepreneurship education, especially in physics. The author takes into account the role of Facebook in promoting physics message through "Physics Learning Shirt-theme" [short: Physics T-shirt, see Figure 1]. The main inspiration of this idea was to ascertain each undergraduate physics student's capacity to 'think outside the box' and to seeing a vital entrepreneurial competency (Yulianti, Wiyanto, Rusilowati, \& Nugroho, 2020). Science-entrepreneurship encourages each student's entrepreneurial mindset, and measures their ability to adapt to new situations by using different learning topics (such as physics, technology, art, and multimedia), then gave the analysis of the theme there was created.

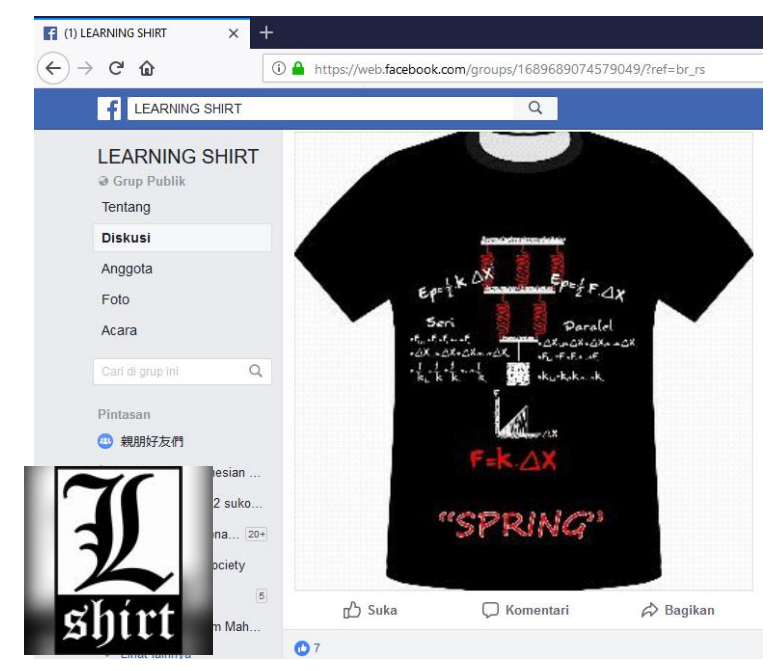

Figure 1. A screenshot of physics learning shirt-theme through Facebook

The study that explores the educational use of FB groups in upper secondary education was done by previous researcher such as (Cheung, Chiu, \& Lee, 2011; Dalsgaard, 2016). Generally, research on the use of FB groups was organized by teachers or lecturers. However, there is a lack of in-depth analysis of FB groups accomplished by students or university students. Therefore, this study will close this gap.

Based on the theoretical foundation and the situation deals with undergraduate physics students above, then two research questions were addressed as follows:

Research Question (RQ) 1: How did the theme of physics learning through physics learning shirt based on thematic analysis?

Research Question (RQ) 2: How did the FB users' understanding on the physics themes on Tshirt?

Research Question (RQ) 3: How did the FB users' responses to the posting activities on Facebook through physics learning shirt? 


\section{Method}

\section{Research Design}

A thematic study has guided this study. "Applied during problem framing, thematic analysis helps researchers move from a broad reading of the data toward discovering patterns and framing a specific research question" (Guest, MacQueen, \& Namey, 2012). Researcher uses thematic analysis as a means to gain insight and knowledge from data gathered [such as Figure 2]. The method empowers researcher to cultivate a deeper appreciation for the member of the group or situation in the group. It is highly inductive: "themes emerge from the data that is gathered and are not imposed or predetermined by the researcher" (Guest, MacQueen, $\&$ Namey, 2012). The research was supported by a group of Indonesian undergraduate physics students on Facebook, namely "Learning Shirt" and the content of their sites. Thirtyfour students from a public university in Surabaya Indonesia contributed to the group's community. These groups of students established entrepreneurship activities and promoted their message or information of physics via FB. The role of these students is the entrepreneurs, meanwhile 192 active members in FB as the service users. The role of the researcher is the tutor of this community.

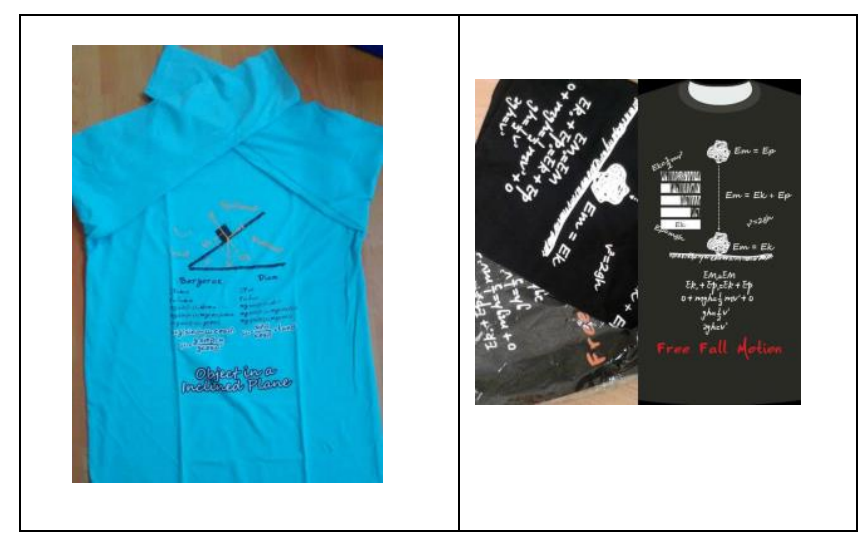

Figure 2. The performance of physics learning shirt-theme

\section{Procedure and Analysis}

In simple, the procedure of thematic study in this research includes: "generating initial codes $\rightarrow$ searching for themes $\rightarrow$ reviewing themes $\rightarrow$ defining and naming themes $\rightarrow$ producing the report" (Braun \& Clarke, 2006; Komori, 2018). For completing the step, this research is also provided by test of understanding on the physics themes [see Table 1] and ten items questionnaire to express the FB user's response to the learning shirt. Each user has opportunities to choose more than one expression or item based on his/ her feeling.

Theoretically, the data collection in the thematic study is gathered from sources field diaries, observational data, pictures/video, historical data, questionnaire statements, and transcripts of audio recording (Braun \& Clarke, 2006). However, the researcher used observational data and relevant pictures and video as collecting data in the first step. 
The second step is coding data. In this step, the researcher codes the data manually by handling images, concepts, keywords, and reflections. Coding is an exact process in which the researcher will transform the analysis as echoed by the data and as ideas emerge. A right code is "one that captures the qualitative richness of the phenomenon" (Boyatzis, 1998). Code becomes the underpinning for the themes that are going to be used by the researcher.

The third step is code validation. The purpose of this step is to ensure the integrity of the codes in order to avoid misinterpretation and researcher bias. Therefore, it should be developed and reviewed by more than one validator - the double-checking of the codes by reading and re-reading the data, for reliability and validity.

The fourth step is themes identification. The researcher identifies themes and subthemes that have emerged from the coded data. They need to be able to define each theme sufficiently so that it is clear to others exactly what the theme is.

The last step is information consolidation. As researcher, the author finalizes the name of each theme, write its description and illustrate it with a few quotations to give its meaning to the reader as shown on Table 1 .

Table 1. List of themes and physics content of learning-shirt

\begin{tabular}{cl}
\hline \multicolumn{1}{c}{ Theme } & \multicolumn{1}{c}{ Physics content collection } \\
\hline History of physics & Galileo Galilei, Sir Isaac Newton, Albert Einstein \\
\hline $\begin{array}{c}\text { Derivation of } \\
\text { Equation in Physics }\end{array}$ & $\begin{array}{l}\text { Einstein's theory, Atwood machine, simple pendulum, } \\
\text { projectile motion, spring, venturi meter }\end{array}$ \\
\hline Physics symbols & All physics symbols, all physics equations: fundamental \\
and equations & quantities, atomic orbital, \\
\hline Physics values & Physics value of relative motion, physics value of Newton law, \\
& physics of mathematics, collision, inverting amplifier. Electron \\
& behavior \\
\hline Models in Physics & AND-OR-NOT-NAND, atomic models \\
\hline
\end{tabular}

\section{Results and Discussion}

\section{Results}

RQ 1: How did the theme of physics learning through physics learning shirt based on thematic analysis?

The following results based on RQ 1 are the sample of physics content on learning shirt in accordance with its theme.

\subsection{First theme: History of Physics}

The promotion of science (physics) cannot be separated from the three fundamental foundations: philosophy of science (POS), history of science (HOS), and nature of science (NOS). Figure 3 represents one of the examples of the history of physics as a theme in 
Physics learning shirt. The shirt gives physics learning: A brief biography of Albert Einstein (1879-1955), with the following interpretation:

"Albert Einstein was a theoretical physics scientist who was widely regarded as the greatest and most famous scientist in the 20th century. He put forward the theory of relativity and also contributed greatly to the development of quantum mechanics, statistical mechanics, and cosmology. He was awarded the Nobel Prize in Physics for his dedication to theoretical physics which developed the general theory of relativity in 1921. One of the most well-known formulas that made him known to many was the formula for the Theory of Relativity, $E=m c^{2}$ ".

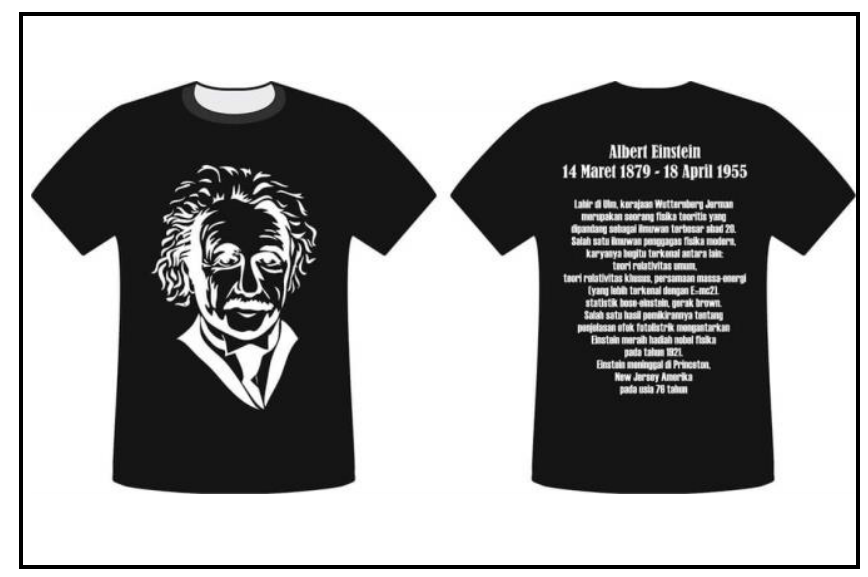

Figure 3. The example of theme: history of physics

\subsection{Second theme: Derivation of Equation in Physics}

In physics, equation derivation is the equation that expresses new quantities in terms of base quantities. Figure 4, 5, and 6 give three examples of this theme. From Figure 4, we learn the theory of special relativity from Einstein. The interpretation of the theme in the shirt is:

"The theory of special relativity was developed by Albert Einstein in 1905, and it forms part of the basis of modern physics. After finishing his work in special relativity, Einstein spent a decade pondering what would happen if one introduced acceleration".

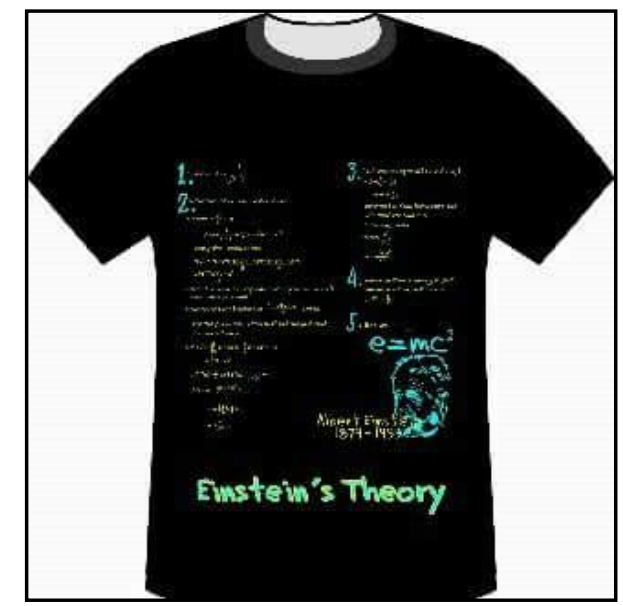

Figure 4. The example of theme: derivation of Einstein's theory 
Figure 5 performs the derivation of acceleration and tension in the pulley system through the Atwood machine. The interpretation of the theme in the shirt is:

"The Atwood machine is a basic physics laboratory device that is often used to demonstrate the basic principles of dynamics and acceleration. Machines usually involve pulleys, ropes, and mass systems. Based on the picture, the form of physics learning through $t$-shirts is the process of obtaining the amount of acceleration and tension in the pulley system that utilizes the principle of Atwood".

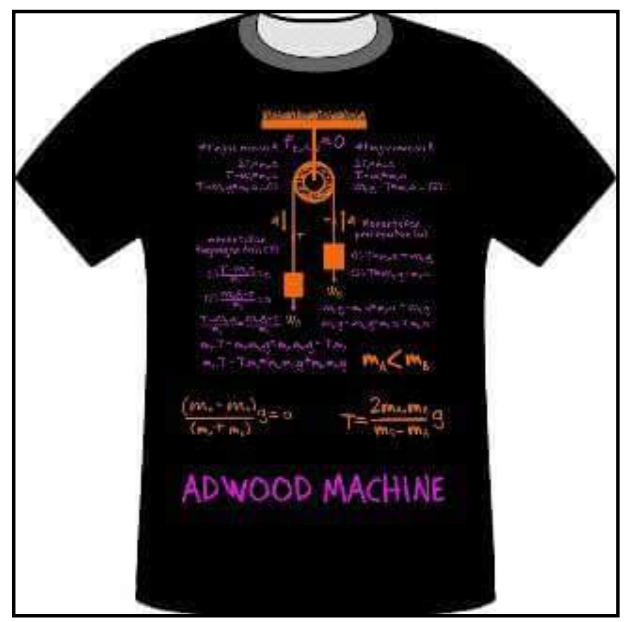

Figure 5. The example of theme: derivation of Atwood machine

Meanwhile, Figure 6 illustrated the derivation of period in simple pendulum.

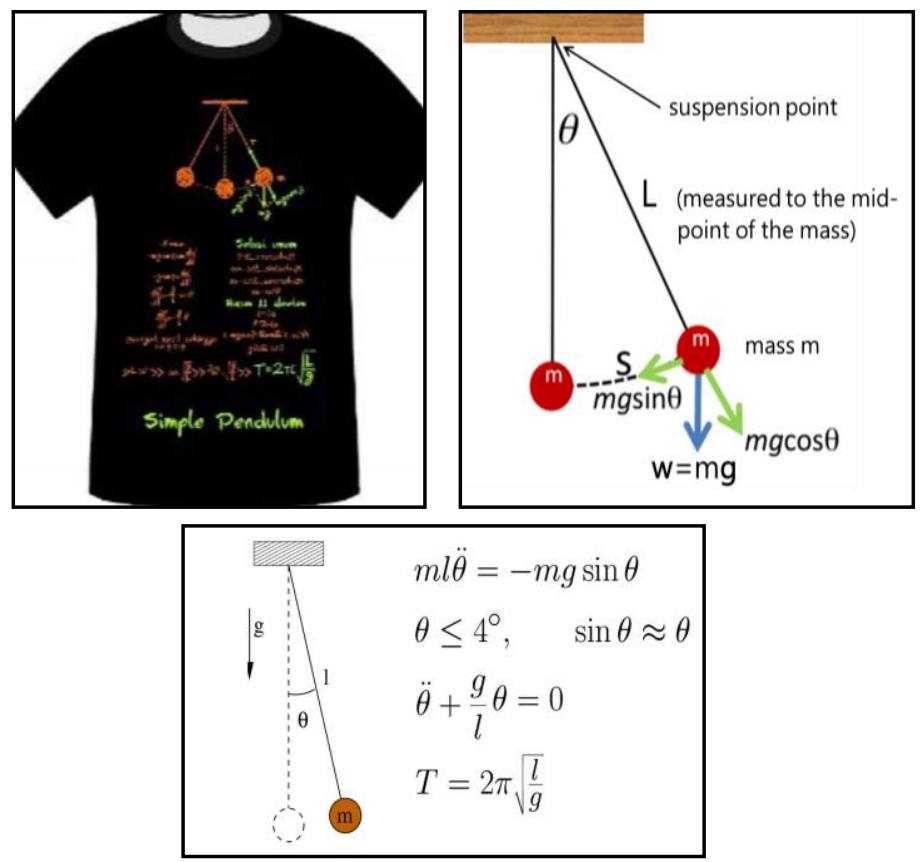

Figure 6. The example of theme: derivation of simple pendulum

\subsection{Third theme: Physics symbols and equations}

Symbols are indicating physical quantities, units, astronomical bodies, constellations, relationships, mathematical operations, and the Greek alphabet. Figure 7 gives an example of the performance of physics symbol and equation together. A lot of physics quantities were summarized in the equation and shaped a tree. 


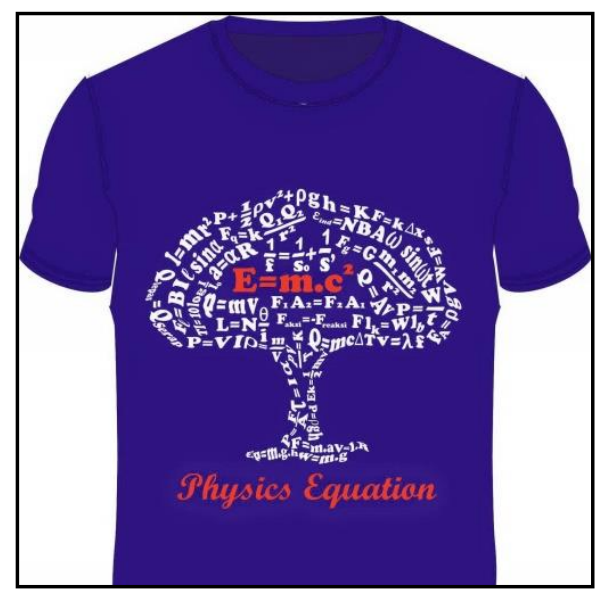

Figure 7. The example of theme: physics symbol and equation

\subsection{Fourth theme: Physics values}

There is any relationship between moral value and physics. For example, Capraro \& Perc (2018) used the term "social physics" in demonstrating how Methods of statistical physics have confirmed valuable for studying of a social dilemma. Another example is teaching physics with moral objectives (Weber, 1937). Figure 8 and Figure 9 perform the illustration of physics values in relative motion and Newton's law.

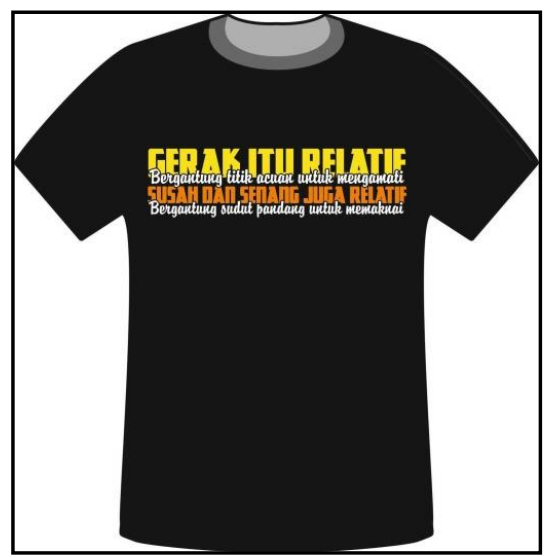

Figure 8. The example of theme: physics value of relative motion

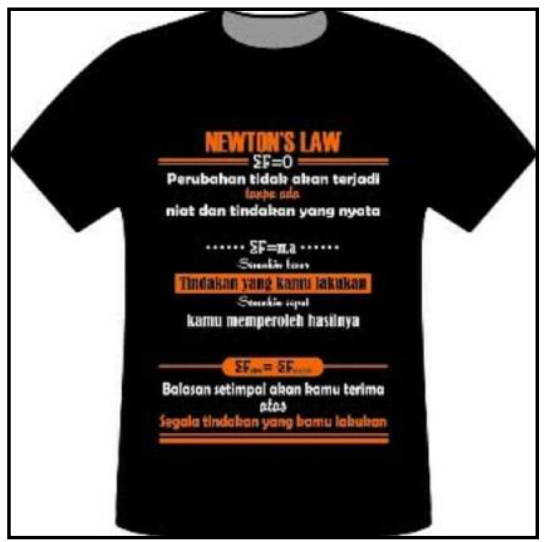

Figure 9. The example of theme: physics value of Newton's law 


\subsection{Fifth theme: Models in Physics}

Model is essential both in the development of physics itself and in promoting physics. Historically, the consensus models of physics are targeted to embody particular ontological assumptions and epistemological commitments (Hart, 2008). Figure 10 reflects on why the author has found particular models valuable in promoting physics on the L-shirt. It transfers from AND-OR-NOT-NAND in physics becomes ANDROID-ORDROID-NOTDROIDNANDROID.

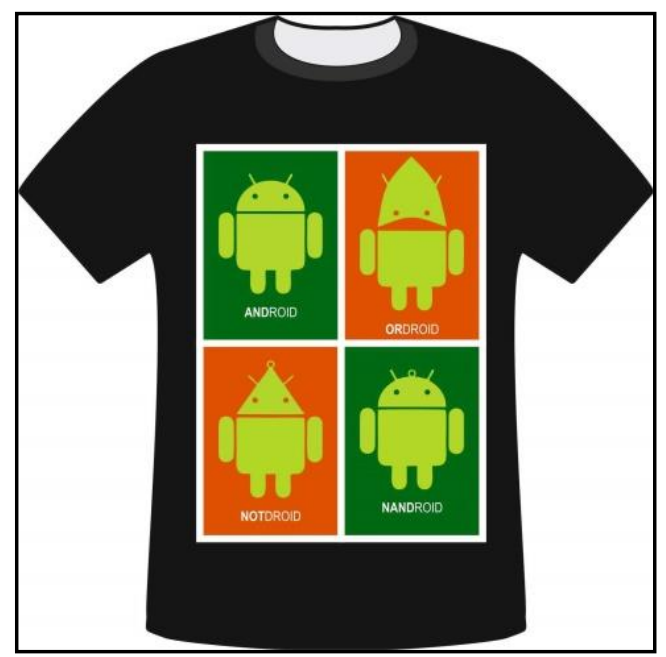

Figure 10. The example of theme: model in physics

\section{RQ 2: Research Question (RQ) 2: How did the FB users' understanding on the physics themes on T-shirt?}

In order to explore the FB users' understanding on the five themes provides, and then the online test was conducted. Generally speaking, the average score of the users' understanding was 79.79 out of 100 (Figure 11).

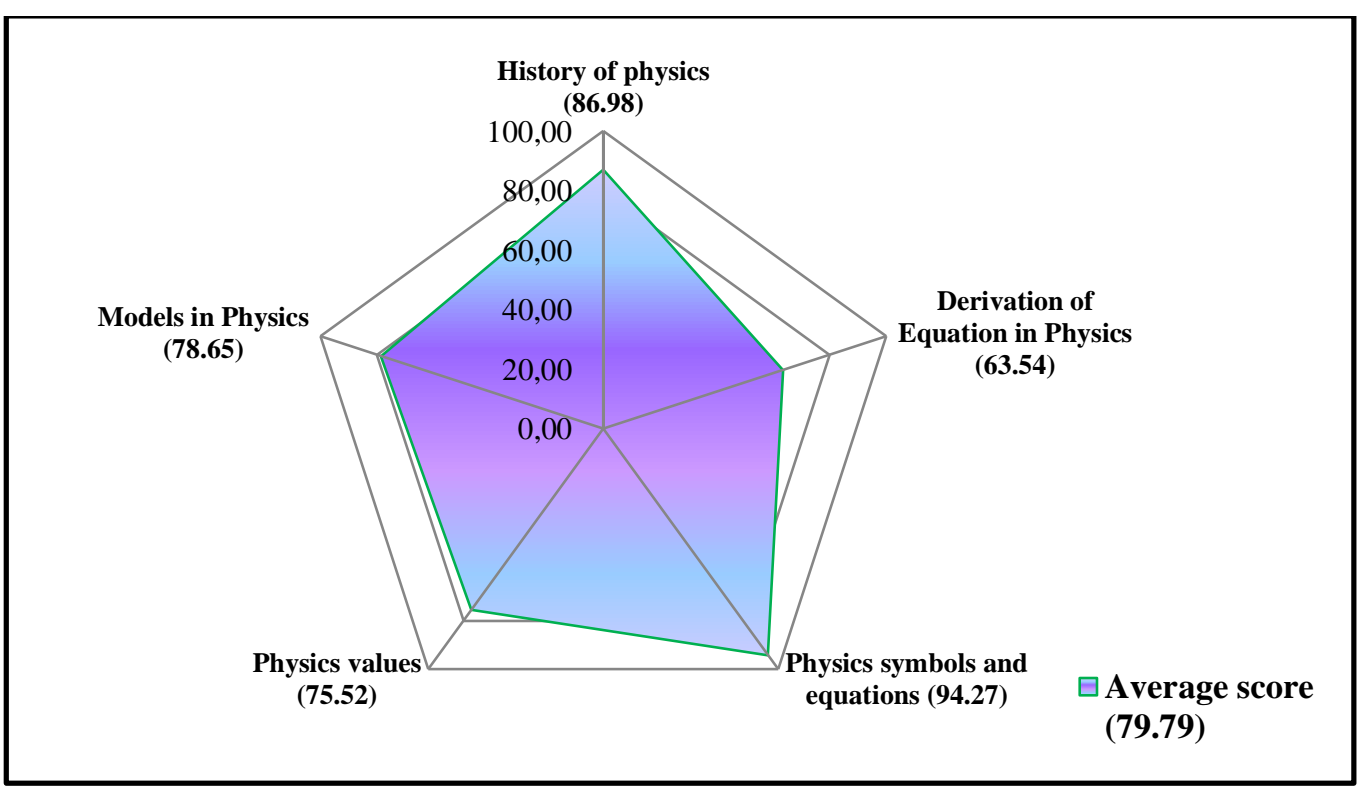

Figure 11. FB users' understanding on the physics themes on T-shirt 
Meanwhile, the users performing better in physics symbols and equations (94.27) than other themes. In contrast, they performed less in derivation of equation in physics (63.54). This performance could be explained that physics symbols and equations simpler than derivation of equations. Additionally, physics symbols are easier for respondents to memorize and remember.

\section{$>$ RQ 3: How did the FB users' responses to the posting activity in Facebook through physics learning shirt?}

After the physics learning- shirt was posted in FB with varieties of the theme [history, derivation, symbols, values, and models of physics], 192 active group members in FB and non-group members as the service users were asked to complete the 10-items questionnaire (Table 2). Then, the result of the response is illustrated in Figure 12.

Table 2. Questionnaire's item of FB user's response regarding the physics learning-shirt

\begin{tabular}{clcl}
\hline Item & \multicolumn{1}{c}{ Expression } & Item & \multicolumn{1}{c}{ Expression } \\
\hline 1 & $\begin{array}{l}\text { I found the idea of learning shirt } \\
\text { is new }\end{array}$ & 6 & $\begin{array}{l}\text { I like all the option of themes provided } \\
\text { in learning-shirt }\end{array}$ \\
\hline 2 & $\begin{array}{l}\text { The theme in Learning shirt is } \\
\text { relatively new }\end{array}$ & 7 & $\begin{array}{l}\text { I will share this best practice to my } \\
\text { friend }\end{array}$ \\
\hline 3 & $\begin{array}{l}\text { The content of physics in } \\
\text { Learning shirt is interesting }\end{array}$ & 8 & I like learning science through T-shirt \\
\hline 4 & $\begin{array}{l}\text { I will give another suggestion of } \\
\text { the theme in FB's forum }\end{array}$ & 9 & $\begin{array}{l}\text { Promoting Learning shirt in FB is kind } \\
\text { of online-entrepreneurship }\end{array}$ \\
\hline 5 & I like the design of the shirt & 10 & Finally, I order the Learning-shirt \\
\hline
\end{tabular}

FB users gave a different response regarding the physics learning-shirt in duration of three weeks among ten items of questionnaire. Item number 3. 6, and 9 got more attention than other seven items. Item number 9 as an example, it asked about promoting learning-shirt in FB and the respondents perceived learning-shirt is kind of online-entrepreneurship. Then, item number 6, the FB users prefer to all the option of themes provided in learning-shirt. Turning to item 3, the users were also interested to the content of physics in Learning-shirt. 

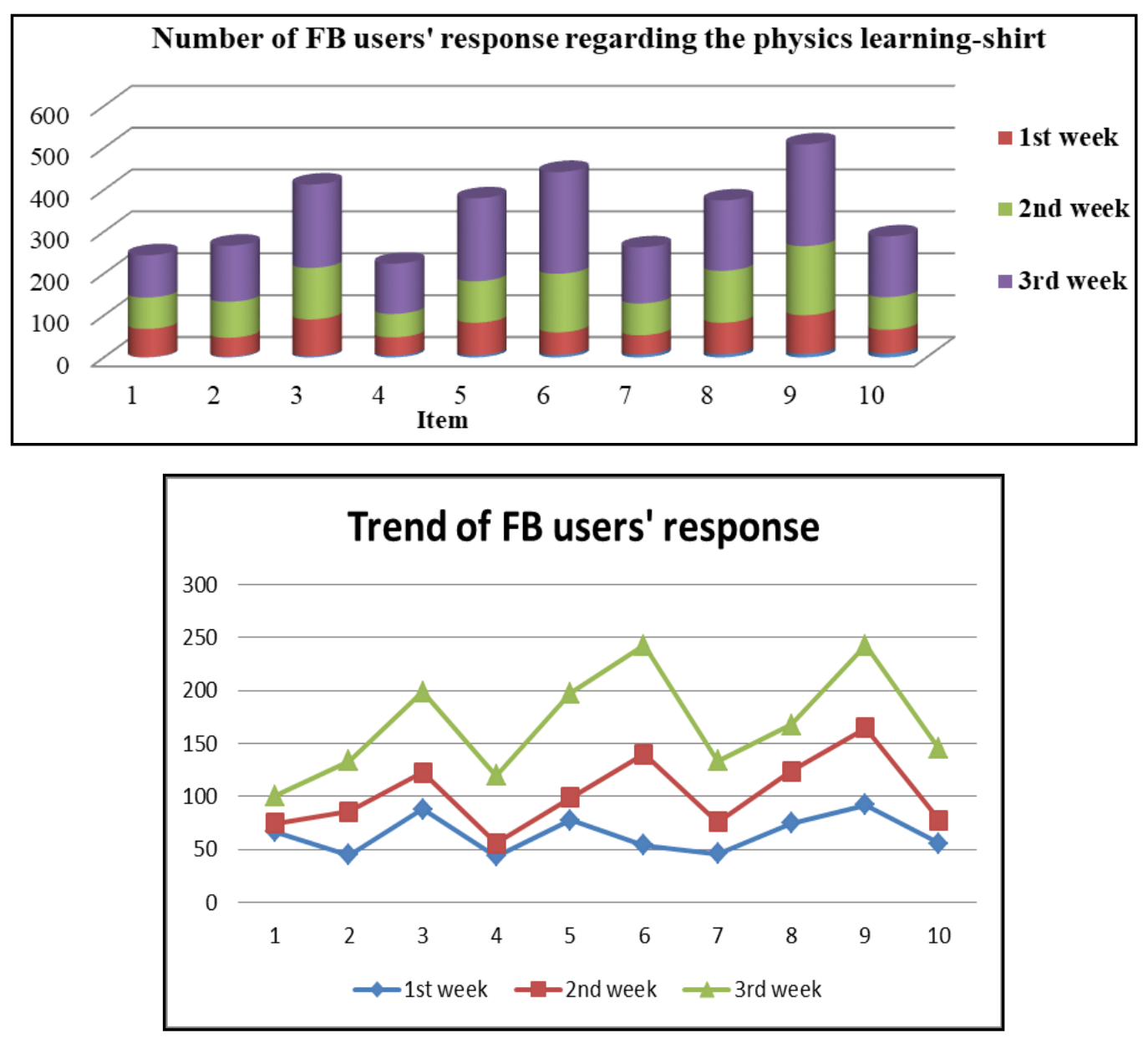

Figure 12. The FB users' responses to the posting activity in Facebook

Generally speaking, the trend of FB user's response regarding ten expressions in the questionnaire was increased significantly. Induration of three weeks, more than 300 hints indicated that the content of physics in learning shirt exotic, the design and the theme is attractive. They also percept that learning science through $\mathrm{T}$-shirt is lovely and they agree, promoting learning shirt in FB is online-entrepreneurship.

\section{Discussion}

Based on RQ 1, it was summarized five themes of physics learning shirt: the history of physics, derivation of the equation in physics, physics symbols and equations, physics values, and models in physics. The choice of this theme is based on a possible representation of the physics content that can be seen by either a physicist or a layman. This study points out the benefits and the potency of developing science entrepreneurship either via a similar media or other media. The users learned many positive and moral messages through symbols, equations, models, and history of physics. The authors and the initiator of the Learning shirt community in FB have also got the benefit from selling the T-shirt and the users buy it. FB's group activity aims to encourage an entrepreneurial mind-set in undergraduate physics students and to equip them with techniques for use in their future teaching. As a tutor, the researcher exemplifies and adopts the FIRE model as promoted by the European Commission 
regarding the model of entrepreneurship education that involves four specific and interrelated stages (European, 2013).

Table 3. FIRE model of entrepreneurship

\begin{tabular}{cl}
\hline $\mathbf{F}$ & "Finding facts (from resources + real life)" \\
\hline $\mathbf{I}$ & "Innovative ideas (generating + selecting)" \\
\hline $\mathbf{R}$ & "Reality check (through prototyping + \\
& feedback)" \\
\hline $\mathbf{E}$ & $\begin{array}{l}\text { "Evaluation (of product + process and } \\
\text { learning)" }\end{array}$ \\
\hline
\end{tabular}

Turning to the RQ 2, It can be summarized that the representation of physics themes on the T-shirt was understood by the FB users. They performed score 79.79 out of 100 among the five themes provided. The minimum average score achieved the users in the theme of derivation of equation in physics. Meanwhile, the maximum score achieved by them in the theme of physics symbols and equations. Social media like Facebook is one of the ways to foster an entrepreneurial spirit in our business (Clement, 2020). These findings implied through the Facebook, the success of entrepreneurship is realized as well as the understanding of the science concept is achieved (Akani, 2012; Deveci \& Çepni, 2017; Dhyab \& Varol, 2018; Jumaat, et al., 2019) with the two main indicators: success in moral and value message and economic benefit. It means Facebook is useful in optimizing science-entrepreneurship.

Then, in regards to RQ 3, through learning-by-doing empowers students to develop their entrepreneurial skills and enhances their knowledge of social businesses. A group of Indonesian undergraduate physics students (34 members) in FB namely "Learning Shirt" practice to design and to perform their creativity in design learning-shirt. The students became more effective in formulating, applying appropriate business strategies, and working in teams (Chang, Benamraoui, \& Rieple, 2014). It was seen that the social entrepreneurship skills of undergraduate students were at a high level in terms of self-confidence (Yazıc1, Uslu, \& Arık, 2016). However, this study notes several constraints; sometimes, respondents focus more on business activities than interpreting the physical representations on the shirts. Second, some respondents appreciate the physics content but are not interested in the science entrepreneurship aspect. These two things should be considered for further research.

To test the ability of students to generate new business opportunities when they participated in a redesigned entrepreneurship course with specially developed creativity exercises. This study also emphasizes the previous research that showed the students who contributed as a group member has a significant effect on the abilities to generate a more significant number and more innovative business ideas (Karimi, Biemans, Lans, Aazami, \& Mulder, 2016). Indeed, Ng (2014) summarized some motivation among participation of commercial activities on FB: the convenience of maintaining a relationship, information benefits, and enjoyment, risks of privacy invasion, self-presentation, and social presence.

A previous study has demonstrated that the cultural variations can also be observed in focusing on the self-presentation of photographs on FB (Huang \& Park, 2013). Other studies have also indicated that promoting the content of science-primarily via social media is very 
useful in this era (Adam \& Suprapto, 2019; Suprapto \& Pai, 2015). By using thematic analysis as well as this study, the researcher determines broad patterns in conducting more granular research and data analysis (Guest, MacQueen, \& Namey, 2012). There are many social networking sites, except Facebook such as Instagram, Twitter, Line, WhatsApp, LinkedIn, Foursquare, and Myspace to continue the process of promoting scienceentrepreneurship like the physics learning shirt (Yulianti, Wiyanto, Rusilowati, \& Nugroho, 2020). Formally, we can also utilize MOOCs as a media for developing the content of science (Suprapto \& Pai, 2015). Thus, many resources are suitable for entrepreneurial learning activities.

\section{Conclusion}

There were three main conclusions to encounter the three research questions:

1. This study resulted five themes of physics learning shirt: the history of physics, derivation of the equation in physics, physics symbols and equations, physics values, and models in physics.

2. The physics representation of T-shirt themes was understood by the FB users in a good category. They performed score 79.79 out of 100 among the five themes provided.

3. FB users gave a positive response regarding ten expressions in the questionnaire and the trend of response was increased significantly in three weeks. Through learning-by-doing empowers students to develop their entrepreneurial skills: effective in formulating and designing a specific product, applying appropriate business strategies, working in teams, and enhances their knowledge of social businesses.

\section{Acknowledgments}

Thanks to the group of Physics Learning Shirt community with their creativity, the themes were established. Special thank is addressed to Muh Hakim Alhamidy and Putri Indriana as the initiator of the Learning shirt community in FB.

\section{References}

Adam, A. S., \& Suprapto, N. (2019). One-stop physics e-book package development for senior high school learning media. International Journal of Emerging Technologies in Learning, 14(19), 150-158.

Agommuoh, P. C., \& Akanwa, U. N. (2014). Senior secondary school physics teachers' assessment of entrepreneurial skills needed for global competitiveness. IOSR Journal of Research \& Method in Education, 4(1), 25-29.

Akani, O. (2012). Integrating entrepreneurial education into science and technology curriculum: A strategy for poverty and unemployment reduction in Nigeria. World Educator Forum, 1-16.

Armstrong, P., \& Tomes, A. (2000). Entrepreneurship in science: Case studies from liquid crystal application. Prometheus, 18(2), 133-147.

Arouri, Y. M. (2015). How Jordanian university students perceive the opportunities and challenges of using Facebook as a supplementary learning Resource. International Journal of Emerging Technologies in Learning, 10(1), 46-54. 
Boyatzis, R. E. (1998). Transforming qualitative information: Thematic analysis and code development. London: SAGE Publications, Inc.

Boyd, D. M., \& Ellison, N. B. (2007). Social network sites: Definition, history and scholarship. Journal of Computer-Mediated Communication, 13(1), 210-230.

Braun, V., \& Clarke, V. (2006). Using thematic analysis in psychology. Qualitative Research in Psychology, 3(2), 77-101.

Bumgarner, B. A. (2007). You have been poked: The uses and gratifications of Facebook among emerging adults. First Monday, 12(11).

Capraro, V., \& Perc, M. (2018). Grand challenges in social physics: In pursuit of moral behaviour. Frontiers Physics, 6, 107.

Chang, J., Benamraoui, A., \& Rieple, A. (2014). Learning-by doing as an approach to teaching social entrepreneurship. Innovations in Education and Teaching International, 51(5), 459-471.

Cheung, C. M., Chiu, P. Y., \& Lee, M. K. (2011). Online social networks: Why do students use Facebook. Computers in Human Behavior, 27, 1337-1343.

Clement, J. (2020). Number of Facebook users worldwide 2008-2019.

Dalsgaard, C. (2016). Students' educational use of Facebook groups. Educational Media International, 53(4), 261-273.

Deveci, İ., \& Çepni, S. (2017). Studies conducted on entrepreneurship in science education: Thematic review of research. Journal of Turkish Science Education, 14(4), 126-143.

Dhyab, R., \& Varol, A. (2018). Distance education features using Facebook. International Journal of Interactive Mobile Technologies, 12(6), 19-34.

Ejilibe, O. C. (2012). Entrepreneurship in biology education as a means for employment. Knowledge Review, 26(3), 96-100.

Ellison, N. E., Steinfield, C., \& Lampe, C. (2007). The benefits of Facebook friends: Social capital and college students' use of online social network sites. Journal of Computer Mediated Communication, 12(4), 1143-1168.

European, C. (2013). Entrepreneurship education: A guide for educators. European Union, Bruxelles: Entrepreneurship and Social Economy Unit.

Ezeudu, F. O., Ofoegbu, T. O., \& Anyaegbunnam, N. J. (2013). Restructuring STM (Science, Technology, and Mathematics) education for entrepreneurship. US-China Education Review A, 3(1), 27-32.

Gapsalamov, A. R., Bochkareva, T. N., Akhmetshin, E. M., Vasilev, V. L., \& Anisimove, T. I. (2020). Digital society: New challenges for education (Sociedade digital: Novos desafios para a educação). Periodico Tche Quimica, 17(34), 803-816.

Guest, G., MacQueen, K. M., \& Namey, E. E. (2012). Applied thematic analysis. London: SAGE Publications, Inc.

Hart, C. (2008). Models in physics, models for physics learning, and why the distinction may matter in the case of electric circuits. Research in Science Education, 38, 529-544.

Huang, C. M., \& Park, D. (2013). Cultural influences on Facebook photographs. International Journal of Psychology, 48(3), 334-343.

Jumaat, N. F., Ahmad, N., Samah, N. A., Ashari, Z. M., Ali, D. F., \& Abdullah, A. H. (2019). Facebook as a platform of social interactions for meaningful learning. International Journal of Emerging Technologies in Learning, 14(4), 151-159. 
Kalpidou, M., Costin, D., \& Morris, J. (2011). The relationship between Facebook and the well-being of undergraduate college students. Cyberpsychology, Behavior and Social Networking, 14(4), 183-189.

Karimi, S., Biemans, H. J., Lans, T., Aazami, M., \& Mulder, M. (2016). Fostering students' competence in identifying business opportunities in entrepreneurship education. Innovations in Education and Teaching International, 53(2), 215-229.

Kocdar, S., Karadeniz, A., \& Goksel, N. (2018). Using Facebook for leveraging sense of community in self-paced open and distance learning courses. International Journal of Emerging Technologies in Learning, 13(5), 100-116.

Komori, M. (2018). Thematic analysis. http://designresearchtechniques.com/casestudies/thematic-analysis/.

Mason, R. (2006). Learning technologies for adult continuing education. Studies in Continuing Education, 28(2), 121-133.

McEwen, T. (2013). Ecopreneurship as a solution to environmental problems: Implications for college level entrepreneurship education. International Journal of Academic Research in Business and Social Sciences, 3(5), 264-288.

Nacu, C. M., \& Avasilcăi, S. (2014). Technological ecopreneurship: Conceptual approaches. Procedia - Social and Behavioral Sciences, 124, 229-235.

NapoleonCat. (2019). Facebook users in Indonesia. Retrieved from https://napoleoncat.com/stats/facebook-users-in-indonesia/2019/01.

$\mathrm{Ng}$, M. (2014). Consumer motivations to disclose information and participate in commercial activities on Facebook. Journal of Global Scholars of Marketing Science: Bridging sia and the World, 24(4), 265-383.

Nwakaego, O. N., \& Kabiru, A. M. (2015). The need to incorporate entrepreneurship education into chemistry curriculum for colleges of education in Nigeria. Journal of Educational Policy and Entrepreneurial Research, 2(5), 84-90.

Sanchez-Franco, M. J., Villarejo-Ramos, A. F., \& Martin-Velicia, F. A. (2011). Social integration and post-adoption usage of social network sites: An analysis of effects on learning performance. Procedia - Social and Behavioral Sciences, 15, 256-262.

Scale, M. (2008). Facebook as a social search engine and the implications for libraries in the twenty first century. Library Hi Tech, 26(4), 540-556.

Shraim, K. (2014). Pedagogical innovation within Facebook: A case study in tertiary education in Palestine. International Journal of Emerging Technologies in Learning, 9(8), 25-31.

Suprapto, N., \& Pai, Y. F. (2015). Promoting science centers by using MOOCs: Model for communicating informal science education. Man in India, 95(4), 1005-1012.

Teo, T. (2016). Modelling Facebook usage among university students in Thailand: The role of emotional attachment in an extended technology acceptance model. Interactive Learning Environments, 24(4), 745-757.

Weber, L. R. (1937). Teaching physics with moral objectives. Christian Education, 20, 350.

Yazıc1, K., Uslu, S., \& Arık, S. (2016). The investigation of the social entrepreneurship characteristics of social studies pre-service teachers. Cogent Education, 3, 1141455. 
Yulianti, D., Wiyanto, Rusilowati, A., \& Nugroho, S. E. (2020). Development of physics learning teaching materials based on science technology engineering and mathematics to develop 21st century learning skills. Periodico Tche Quimica, 17(34), 711-717. 